\title{
Implementasi Manajemen Risiko Berdasarkan PMBOK Untuk Mencegah Keterlambatan Proyek Area Jawa Timur (Studi Kasus: PT. Telkom)
}

\author{
Havea Pertiwi \\ Magister Manajemen Teknologi, Institut Teknologi Sepuluh Nopember \\ E-mail: \\ havea.pertiwi@gmail.com
}

\begin{abstract}
ABSTRAK
Peningkatan jumlah pengguna mendorong percaturan bisnis telekomunikasi berkembang menjadi lebih baik, hal ini mengakibatkan persaingan di bidang tersebut semakin ketat. PT. Telekomunikasi Indonesia, Tbk sedang melakukan proyek pembaruan infrastrukturnya. Pada tahun 2015, terjadi peningkatan jumlah proyek secara signifikan yang dikelola oleh Telkom Jawa Timur yaitu mencapai angka 105 proyek dan belum menerapkan manajemen risiko.

Berdasarkan latar belakang tersebut digunakan pendekatan manajemen risiko proyek dengan standar Project Management Body of Knowledge (PMBOK) yang diterbitkan tahun 1983 oleh Project Management Institute (PMI). Adapun tools untuk mengukur risiko digunakan metode Failure Modes and Effects Analysis (FMEA).

Risiko yang menjadi prioritas dari hasil penelitian yaitu risiko keterbatasan kualifikasi tenaga kerja Mitra, adanya new item dalam pekerjaan yang belum terdapat dalam List of Materials, keterlambatan pengurusan perijinan/ sitac/ PLN/ pihak ketiga, kesalahan perhitungan nilai realisasi proyek, keterbatasan jumlah tenaga kerja Mitra, perbaikan pekerjaan yang sudah selesai (rework), kurangnya komunikasi dan koordinasi, keterlambatan pemesanan material ke pabrik.
\end{abstract}

Kata Kunci: Manajemen Risiko, Project Management Body of Knowledge (PMBOK), FMEA

\section{ABSTRACT}

The increase in the number of users of telecommunications pushed the business arena 
evolving for the better, this results in the field of competition is getting tougher. PT. Telekomunikasi Indonesia, Tbk is doing its infrastructure renewal project. In 2015, an increasing number of significant projects managed by Telkom East Java, reached 105 projects and have yet to implement risk management.

Based on this background to use a risk management approach to the project standard Project Management Body of Knowledge (PMBOK) published in 1983 by the Project Management Institute (PMI). As tools for measuring risk used method of Failure Modes and Effects Analysis (FMEA).

Risks are the priorities of the research is the risk limitations workforce qualifications Partners, the new items in a job that is not in the List of Materials, the delay of the necessary permits / SITAC / PLN / a third party, a calculation error realizable value of the project, the limited amount of manpower Partners, repair work already completed (rework), lack of communication and coordination, delays in ordering material to the mill.

Keywords: Risk Management, Project Management Body of Knowledge (PMBOK), FMEA

\section{PENDAHULUAN}

PT. Telekomunikasi Indonesia Tbk sedang melakukan proyek pembaruan infrastrukturnya. Pada tahun 2015, terjadi peningkatan jumlah proyek yang sangat signifikan yang dikelolah oleh Telkom Jawa Timur yaitu mencapai angka 105 proyek. Dalam studi kasus yang akan diteliti, yaitu daerah proyek pembangunan Jawa Timur khusus kepada proyek OSP yaitu modernisasi perangkat RK. Berdasarkan data yang diperoleh dua tahun terakhir (2014-2015) terdapat 17 proyek modernisasi (929 node), dan $45 \%$ yang dikelola mengalami keterlambatan waktu penyelesaian.

Keterlambatan penyelesaian disebabkan oleh banyak faktor baik itu internal maupun eksternal yang muncul sejak tahap awal pelaksanaan proyek, yaitu tahap desain, proses pengadaan, pelaksanaan hingga serah terima. Oleh karena itu, manajemen risiko harus dilakukan di seluruh siklus proyek dari tahap awal sampai akhir proyek (Project Risk Management Handbook, 2007).

Menurut Assaf et al (1995) menyebutkan bahwa penyebab keterlambatan antara lain dapat dilihat dari sisi material, tenaga kerja, peralatan, biaya , perubahan-perubahan desain, hubungan dengan instansi terkait, penjadwalan dan pengendalian, lambatnya prosedur pengawasan dan pengujian yang dipakai dalam proyek, lingkungan, masalah kontrak, dan tidak adanya konsultan manajer profesional.

Saat ini belum diterapkan manajemen risiko yang spesifik, yang dilakukan baru sebatas identifikasi penyebab keterlambatan. Oleh karena itu sesuai dengan tujuan penelitian akan diidentifikasi risiko penyebab keterlambatan proyek dengann menggunakan pendekatan manajemen risiko proyek mengacu pada standar Project Management Body of Knowledge (PMBOK) yang dipopulerkan oleh Project Management Institute (PMI). Adapun kelebihan yang menjadi alasan dipilihnya PMBOK yaitu merupakan praktek terbaik berdasarkan pengalaman dan pengetahuan secara luas yang dibuat dalam bentuk framework yang fokus pada disiplin manajemen proyek sehingga penerapan yang benar dari metode manajemen yang disarankan ini akan memberi peluang lebih besar untuk mencapai sukses pada proyek di berbagai 
sektor pekerjaan. Setelah identifikasi akan dibuatkan prioritas risiko dan usulan mitigasinya.

PMBOK merupakan suatu buku yang mencantumkan terminologi standar dan pedoman untuk manajemen proyek yang diterbitkan pertama kali pada tahun 1983 oleh Project Management Institute (PMI). Edisi keempatnya diterbitkan pada tahun 2008 dan mencantumkan manajemen risiko proyek sebagai salah satu dari 9 area pengetahuannya. Ada 6 proses manajemen risiko proyek yang dicantumkan dalam PMBOK ini, yaitu: perencanaan manajemen risiko, identifikasi risiko, pelaksanaan analisis risiko kualitatif, pelaksanaan analisis risiko kuantitatif, perencanaan tanggapan risiko, pemantauan dan pengendalian risiko.

Adapun untuk tools untuk mengukur risiko digunakan metode Failure Modes and Effects Analysis (FMEA), dimana metode ini cukup populer untuk mengukur penilaian dan pencegahan risiko (Ko, 2013). Identifikasi kegagalan potensial dilakukan dengan cara pemberian nilai atau skor masing - masing moda kegagalan berdasarkan atas tingkat kejadian (Occurrence), tingkat keparahan (severity), dan tingkat deteksi (Detection) (Stamatis, 1995).

\section{KAJIAN PUSTAKA \\ PMBOK (Project Management Body of Knowledge)}

PMBOK merupakan suatu buku yang mencantumkan terminologi standar dan pedoman untuk manajemen proyek yang diterbitkan pertama kali pada tahun 1983 oleh PMI (Project Management Institute). Edisi keempatnya diterbitkan pada tahun 2008 dan mencantumkan manajemen risiko proyek sebagai salah satu dari 9 area pengetahuannya.

Risiko adalah suatu kondisi atau peristiwa tidak pasti yang jika terjadi mempunyai efek positif atau negatif terhadap sasaran proyek. Sebuah risiko mempunyai penyebab dan jika risiko itu terjadi, akan ada konsekuensi. Jika yang terjadi adalah peristiwa yang tidak pasti, maka dampaknya adalah pada biaya, jadwal, dan kualitas proyek. Sedangkan manajemen risiko merupakan suatu seni dan ilmu pengetahuan dalam mengidentifikasi, menganalisis dan merespon terhadap faktor-faktor risiko yang ada selama pelaksanaan suatu proyek.Tahapan dalam manajemen risiko berdasarkan PMBOK membaginya kedalam enam tahapan seperti gambar 1 antara lain:

1. Perencanaan Manajemen Risiko

2. Identifikasi Risiko

3. Pelaksanaan Analisis Risiko Kualitatif

4. Pelaksanaan Analisis Risiko Kuantitatif

5. Perencanaan Tanggapan Risiko

6. Pemantauan Dan Pengendalian Risiko

Gambar 1

Tahapan Manajemen Risiko PMBOK

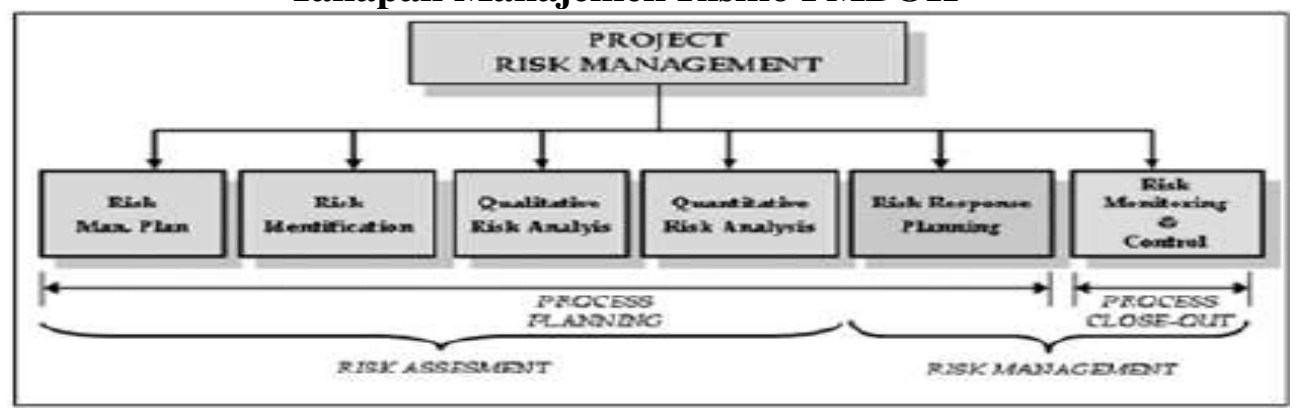




\section{Keterlambatan Proyek}

Pengertian keterlambatan menurut Ervianto (1998) adalah sebagai waktu pelaksanaan yang tidak dimanfaatkan sesuai dengan rencana kegiatan sehingga menyebabkan satu atau beberapa kegiatan mengikuti menjadi tertunda atau tidak diselesaikan tepat sesuai jadwal yang telah direncanakan. Beberapa penyebab yang paling sering terjadi yang mengakibatkan mundurnya waktu penyelesaian proyek antara lain: perubahan kondisi lapangan, perubahan desain atau spesifikasi, perubahan cuaca, ketidak tersedianya tenaga kerja, material, ataupun peralatan.

\section{FMEA (Failure Modes and Effects Analysis)}

FMEA merupakan metode yang digunakan untuk mengidentifikasi resiko yang berpotensi terjadi, menentukan pengaruh resiko tersebut terhadap kegiatan operasional, dan mengidentifikasi tindakan untuk memitigasi resiko tersebut (Crow, 2002).

Manfaat yang ditawarkan dengan diterapkannya metode FMEA yaitu untuk membantu perusahaan meningkatkan kehandalan dan kualitas serta hemat biaya karena sistematis maka penyelesaiannya tertuju pada potensial causes (penyebab yang potential) sebuah kegagalan/ kesalahan. Dan juga hemat waktu karena tepat sasaran.

Tahapan FMEA menurut Manggala (2005) adalah sebagai berikut:

1. Menentukan komponen dari sistem/ alat yang akan dianalisis.

2. Mengidentifikasi potensial failure/ mode kegagalan dari proses yang diamati.

3. Mengidentifikasikan akibat (potential effect) yang ditimbulkan potensial failure mode.

4. Mengidentifikasi penyebab (potential cause) dari failure mode yang terjadi pada proses yang berlangsung.

5. Menetapkan nilai-nilai (dengan jalan observasi lapangan dan brainstorming) dalam point.

Tabel 1

Parameter FMEA

\begin{tabular}{|l|l|}
\hline \multicolumn{1}{|c|}{ Nilai } & \multicolumn{1}{c|}{ Deskripsi } \\
\hline Severity $(S)$ & $\begin{array}{l}\text { Penilaian keseriusan efek dari bentuk kegagalan } \\
\text { potensial. }\end{array}$ \\
\hline Occurrence $(O)$ & Frekuensi terjadinya kesalahan. \\
\hline Detection $(D)$ & Alat kontrol akibat potential cause. \\
\hline $\begin{array}{l}\text { Risk Potential } \\
\text { Number }\end{array}$ & Prioritas resiko. \\
\hline
\end{tabular}

Severity adalah langkah pertama untuk menganalisa resiko yaitu menghitung seberapa besar dampak/ intensitas kejadian mempengaruhi output proses. Adapun nilai 
yang menjabarkan severity dapat dilihat pada tabel severity dibawah ini (Gasper, 2002).

Tabel 2

Rating Severity

\begin{tabular}{|c|c|}
\hline Rangking & Kriteria \\
\hline 1 & $\begin{array}{l}\text { Negligible severity (pengaruh buruk yang dapat diabaikan). Kita } \\
\text { tidak perlu memikirkan bahwa akibat ini akan berdampak pada } \\
\text { kinerja produk. Pengguna akhir mungkin tidak akan } \\
\text { memperhatikan kecacatan ini. }\end{array}$ \\
\hline 2 & $\begin{array}{l}\text { Mild severity (pengaruh buruk yang ringan). Akibat yang } \\
\text { ditimbulkannya hanya bersifat ringan. Pengguna akhir tidak } \\
\text { akan merasakan perubahan kinerja. Perbaikan dapat dikerjakan } \\
\text { pada saat pemeliharaan regular. }\end{array}$ \\
\hline $\begin{array}{l}4 \\
5 \\
6\end{array}$ & $\begin{array}{l}\text { Moderate severity (pengaruh buruk yang moderat). Pengguna } \\
\text { akhir akan merasakan penurunan kinerja, namun masih dalam } \\
\text { batas toleransi. Perbaikan yang dilakukan tidak mahal dan dapat } \\
\text { selesai dalam waktu singkat. }\end{array}$ \\
\hline 8 & $\begin{array}{l}\text { High severity (pengaruh buruk yang tinggi). Pengguna akhir } \\
\text { akan merasakan akibat buruk yang tidak akan diterima, berada } \\
\text { diluar batas toleransi.perbaikan yang dilakukan sangat mahal. }\end{array}$ \\
\hline 10 & $\begin{array}{l}\text { Potential safety problems (masalah keamanan potensial). Akibat } \\
\text { yang ditimbulkan sangat berbahaya dan berpengaruh terhadap } \\
\text { keselamatan pengguna. Bertentangan dengan hukum. }\end{array}$ \\
\hline
\end{tabular}

Occurrence adalah kemungkinan bahwa penyebab tersebut akan terjadi dan menghasilkan bentuk kegagalan selama masa penggunaan produk. Occurrence menunjukkan nilai keseringan suatu masalah yang terjadi karena potential cause. Adapun nilai yang menjabarkan Occurrence dapat dilihat pada tabel Occurrence dibawah ini.

Tabel 3

Rating Occurrence

\begin{tabular}{|c|c|c|}
\hline \multirow{2}{*}{ Degree } & $\begin{array}{c}\text { Berdasarkan pada frekuensi } \\
\text { kejadian }\end{array}$ & Rating \\
\hline \multirow{2}{*}{ Remote } & 0,01 per 1000 item & 1 \\
\hline \multirow{2}{*}{ Low } & 0,1 per 1000 item & 2 \\
\cline { 2 - 3 } & 0,5 per 1000 item & 3 \\
\hline Moderate & 1 per 1000 item & 4 \\
\hline
\end{tabular}




\begin{tabular}{|c|c|c|}
\hline \multirow{2}{*}{ High } & 2 per 1000 item & 5 \\
\cline { 2 - 3 } & 5 per 1000 item & 6 \\
\hline \multirow{3}{*}{ Very High } & 10 per 1000 item & 7 \\
\cline { 2 - 3 } & 20 per 1000 item & 8 \\
\hline
\end{tabular}

Detection merupakan alat control yang digunakan untuk mendeteksi potential cause. Identifikasi metode-metode yang diterapkan untuk mencegah atau mendeteksi penyebab dari mode kegagalan. Adapun nilai yang menjabarkan Detection dapat dilihat pada tabel Occurrence dibawah ini.

Tabel 4

Rating Detection

\begin{tabular}{|c|l|c|}
\hline Rating & \multicolumn{1}{|c|}{ Kriteria } & $\begin{array}{c}\text { Berdasarkan pada } \\
\text { frekuensi kejadian }\end{array}$ \\
\hline 1 & $\begin{array}{l}\text { Metode pencegahan sangat efektif. Tidak } \\
\text { ada kesempatan bahwa penyebab } \\
\text { mungkin muncul. }\end{array}$ & 0,01 per 1000 item \\
\hline 2 & $\begin{array}{l}\text { Kemungkinan penyebab terjadi sangat } \\
\text { rendah. }\end{array}$ & 0,1 per 1000 item \\
\hline 3 & $\begin{array}{l}\text { Kemungkinan penyebab terjadi bersifat } \\
\text { moderat. Metode pencegahan kadang } \\
\text { memungkinkan penyebab itu terjadi. }\end{array}$ & 1000 item \\
\hline 4 & $\begin{array}{l}\text { Kemungkinan penyebab terjadi masih } 1000 \text { item } \\
\text { tinggi. Metode pencegahan kurang }\end{array}$ & 1000 item \\
\hline 7 & $\begin{array}{l}\text { efektif, penyebab masih berulang } \\
\text { kembali. }\end{array}$ & 20 per 1000 item \\
\hline 9 & $\begin{array}{l}\text { Kemungkinan penyebab terjadi sangat } \\
\text { tinggi. Metode pencegahan tidak efektif, } \\
\text { penyebab selalu berulang kembali. }\end{array}$ & 50 per 1000 item \\
\hline 10 & 100 per 1000 item \\
\hline 5
\end{tabular}

Nilai RPN menunjukkan keseriusan dari potential failure, semakin tinggi nilai RPN maka menunjukkan semakin bermasalah. Tidak ada angka acuan RPN untuk melakukan perbaikan. Segera lakukan perbaikan terhadap potential cause, alat kontrol dan efek yang diakibatkan.

RPN merupakan produk matematis dari keseriusan effects (Severity), kemungkinan terjadinya cause akan menimbulkan kegagalan yang berhubungan dengan 
effects (Occurrence), dan kemampuan untuk mendeteksi kegagalan sebelum terjadi pada pelanggan (Detection). RPN dapat ditunjukkan dengan persamaan sebagai berikut :

$$
\mathrm{RPN}=\mathrm{S} * \mathrm{O} * \mathrm{D}
$$

Angka ini digunakan untuk mengidentifikasi risiko yang serius sebagai petunjuk ke arah tindakan perbaikan. Untuk menentukan prioritas risiko yang akan dibuatkanlah diagram pareto.

\section{Diagram Pareto}

Diagram Pareto (Pareto Chart) adalah diagram yang dikembangkan oleh seorang ahli ekonomi Italia yang bernama Vilfredo Pareto (1848-1923). Yang mengatakan bahwa prinsip dasar pareto dihubungkan kepada aturan 80/20, yang artinya $80 \%$ dari masalah ditimbulkan oleh $20 \%$ penyebab. Diagram Pareto digunakan untuk memperbandingkan berbagai kategori kejadian yang disusun menurut ukurannya, dari yang paling besar di sebelah kiri ke yang paling kecil disebelah kanan. Susunan tersebut membantu menentukan pentingnya atau prioritas kategori kejadian-kejadian atau sebabsebab kejadian yang dikaji atau untuk mengetahui masalah utama proses. (Nasution, 2004: 114).

Diagram pareto merupakan kombinasi dua grafik, yaitu grafik batang dan grafik garis. Grafik batang menunjukkan item data yang disusun berurutan dari nilai paling besar hingga paling kecil. Sedangkan grafik garis menunjukkan persen kumulatif terhadap jumlah keseluruhan.

\section{METODOLOGI PENELITIAN}

Melakukan analisis risiko penyebab keterlambatan proyek modernisasi RK dengan mengimplementasikan framework PMBOK. Langkah yang dilakukan adalah melakukan identifikasi risiko dengan cara diskusi dengan manager integrasi dan migrasi serta staff dan juga melakukan studi lapangan dan studi pustaka terkait risiko yang menyebabkan keterlambatan proyek. Dari daftar risiko yang ditetapkan dibuatkanlah kuisioner dengan tujuan mendapatkan nilai S, O, dan D dengan cara menyebarkan kuisioner ke pihak yang yang terkait langsung terhadap proyek. Adapun profil responden sebagai berikut:

\section{Tabel 5}

Profil Responden

\begin{tabular}{|l|l|l|}
\hline Responden & \multicolumn{1}{|c|}{ Masa Kerja } & \multicolumn{1}{|c|}{ Jabatan } \\
\hline R1 & \pm 20 tahun & $\begin{array}{l}\text { Manager Integrasi dan } \\
\text { Migrasi }\end{array}$ \\
\hline R2 & \pm 20 tahun & Staff \\
\hline R3 & \pm 20 tahun & Staff \\
\hline R4 & \pm 20 tahun & Staff \\
\hline R5 & \pm 15 tahun & Staff \\
\hline R6 & \pm 10 tahun & Staff \\
\hline
\end{tabular}


Setelah nilai S,O, dan D diperoleh, dilanjutkan dengan perhitungan nilai RPNnya, sehingga dapat ditentukan prioritas mitigasi risiko.

Gambar 2

\section{Flowchart Penelitian}

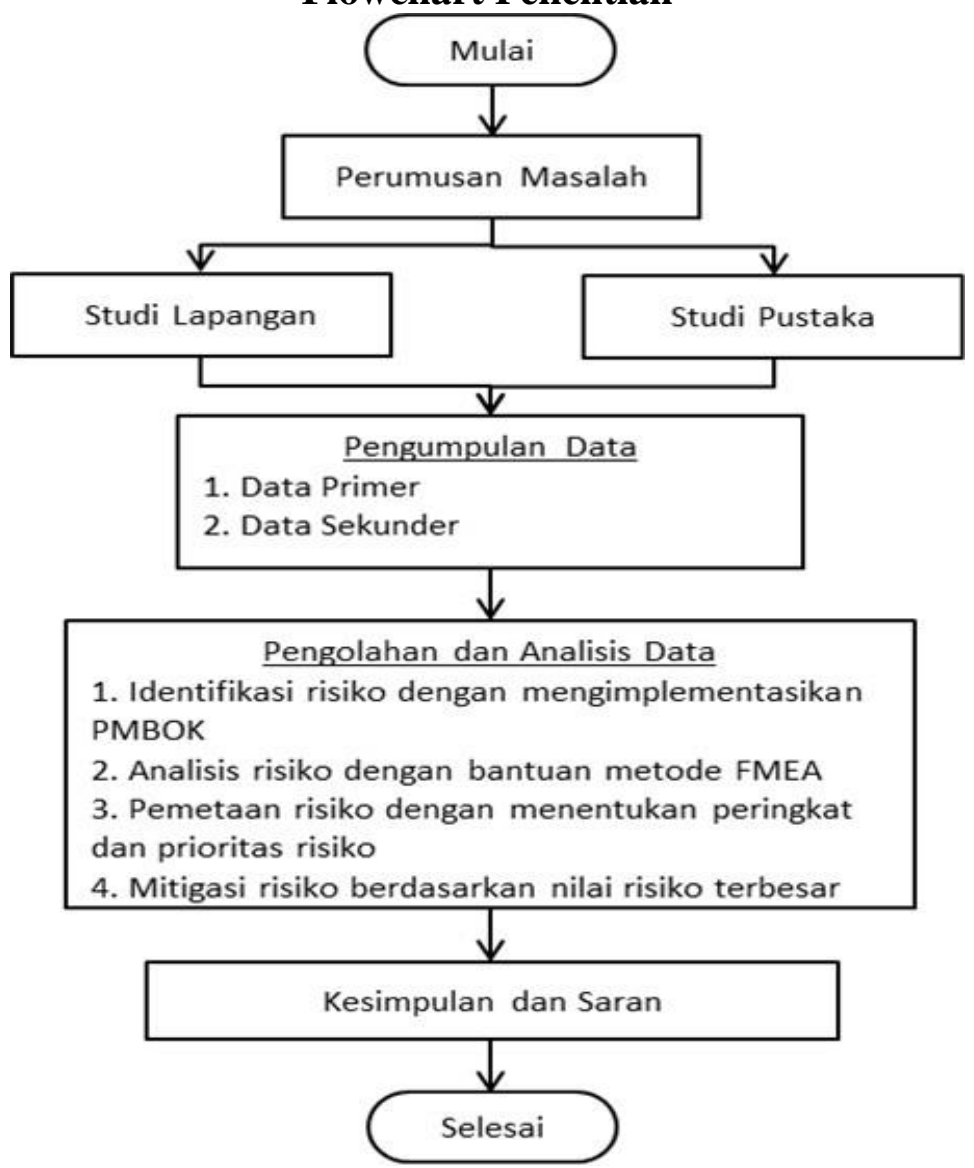

\section{HASIL PENELITIAN DAN PEMBAHASAN}

Berdasarkan aktivitas operasional proyek terdapat 4 proses pada pelaksanaan proyek yaitu proses preparing, proses delivery, proses instalasi \& integrasi, dan terakhir closing. Selanjutnya dilakukan brainstorming dan diskusi dengan Manager Integrasi \& Migrasi serta dengan staff yang sudah berkecimpung di proyek selama lebih dari sepuluh tahun. Dari 4 proses tersebut dijabarkanlah kegagalan yang mungkin terjadi dan risk eventnya yaitu sebanyak 42 risiko.

Berikut daftar 42 risiko dan juga nilai dari severity, occurrence, detection dan juga RPN antara lain:

\section{Tabel 6}

Daftar risiko dengan nilai parameter S,O,D dan RPN

\begin{tabular}{|c|c|c|c|c|c|}
\hline \multirow{2}{*}{ No. } & Potential Failure Mode & \multicolumn{3}{|c|}{ Average } & \multirow{2}{*}{$R P N$} \\
\hline & (Risk Event) & $S$ & $O$ & $D$ & \\
\hline \multicolumn{6}{|c|}{ Kegagalan Kontrak } \\
\hline 1 & $\begin{array}{l}\text { Durasi kontrak/ PO yang terlalu } \\
\text { singkat }\end{array}$ & 5,83 & 5,33 & 4,83 & 150,37 \\
\hline
\end{tabular}




\begin{tabular}{|c|c|c|c|c|c|}
\hline \multirow{2}{*}{ No. } & \multirow{2}{*}{$\frac{\text { Potential Failure Mode }}{\text { (Risk Event) }}$} & \multicolumn{3}{|c|}{ Average } & \multirow{2}{*}{$R P N$} \\
\hline & & $S$ & $O$ & $D$ & \\
\hline 2 & $\begin{array}{l}\text { Bill of Quantity indikatif yang } \\
\text { tidak melalui survey awal }\end{array}$ & 6,00 & 5,00 & 5,33 & 160,00 \\
\hline 3 & $\begin{array}{l}\text { Kesalahan dalam perencanaan } \\
\text { dan spesifikasi }\end{array}$ & 5,67 & 5,67 & 5,50 & 176,61 \\
\hline 4 & $\begin{array}{l}\text { Adanya new item dalam } \\
\text { pekerjaan yang belum terdapat } \\
\text { dalam List of Materials }\end{array}$ & 7,00 & 7,00 & 6,17 & 302,17 \\
\hline 5 & Perubahan scope of work & 5,83 & 4,50 & 5,67 & 148,75 \\
\hline 6 & $\begin{array}{l}\text { Perubahan BOQ yang } \\
\text { mengakibatkan meningkatnya } \\
\text { nilai kontrak } 10 \%\end{array}$ & 7,17 & 5,83 & 4,50 & 188,13 \\
\hline \multicolumn{6}{|c|}{ Kegagalan Desain } \\
\hline 7 & Kesalahan dokumen desain & 6,83 & 5,67 & 4,33 & 167,80 \\
\hline 8 & $\begin{array}{l}\text { Perubahan-perubahan dalam } \\
\text { perencanaan dan spesifikasi }\end{array}$ & 6,00 & 3,83 & 5,17 & 118,83 \\
\hline 9 & $\begin{array}{l}\text { Detail desain yang tidak } \\
\text { lengkap }\end{array}$ & 6,50 & 5,33 & 4,17 & 144,44 \\
\hline \multicolumn{6}{|c|}{ Kegagalan Survey } \\
\hline 10 & Tim survey yang tidak memadai & 6,00 & 2,50 & 4,83 & 72,50 \\
\hline 11 & $\begin{array}{l}\text { Peralatan survey yang tidak } \\
\text { memadai }\end{array}$ & 6,00 & 2,83 & 4,50 & 76,50 \\
\hline 12 & Lokasi survey yang tersebar & 5,67 & 5,33 & 4,33 & 130,96 \\
\hline \multicolumn{6}{|c|}{ Kegagalan Material } \\
\hline 13 & $\begin{array}{l}\text { Keterlambatan } \\
\text { material ke pabrik }\end{array}$ & 6,67 & 6,83 & 5,50 & 250,56 \\
\hline 14 & $\begin{array}{l}\text { Perubahan type material selama } \\
\text { pelaksanaan perkerjaan }\end{array}$ & 7,33 & 5,83 & 4,33 & 185,37 \\
\hline 15 & $\begin{array}{l}\text { Lokasi pemesanan material } \\
\text { yang jauh }\end{array}$ & 4,33 & 5,00 & 3,17 & 68,61 \\
\hline 16 & $\begin{array}{l}\text { Pemesanan jumlah material } \\
\text { yang terbatas }\end{array}$ & 5,50 & 5,00 & 3,50 & 96,25 \\
\hline \multicolumn{6}{|c|}{ Kegagalan Delivery } \\
\hline 17 & $\begin{array}{l}\text { Keterlambatan pengiriman } \\
\text { barang ke site }\end{array}$ & 6,17 & 5,00 & 5,17 & 159,31 \\
\hline 18 & Kesalahan pengiriman barang & 6,83 & 4,33 & 4,67 & 138,19 \\
\hline
\end{tabular}




\begin{tabular}{|c|c|c|c|c|c|}
\hline \multirow{2}{*}{ No. } & Potential Failure Mode & \multicolumn{3}{|c|}{ Average } & \multirow{2}{*}{$R P N$} \\
\hline & (Risk Event) & $S$ & $O$ & $D$ & \\
\hline 19 & $\begin{array}{l}\text { Lokasi pengiriman yang jauh } \\
\text { dari gudang }\end{array}$ & 5,17 & 4,50 & 4,33 & 100,75 \\
\hline \multicolumn{6}{|c|}{ Kegagalan SDM } \\
\hline 20 & $\begin{array}{l}\text { Keterlambatan penunjukan } \\
\text { pelaksana lapangan }\end{array}$ & 6,17 & 3,83 & 5,50 & 130,01 \\
\hline 21 & $\begin{array}{l}\text { Keterbatasan jumlah tenaga } \\
\text { kerja Mitra }\end{array}$ & 7,17 & 6,50 & 5,83 & 271,74 \\
\hline 22 & $\begin{array}{l}\text { Keterbatasan kualifikasi tenaga } \\
\text { kerja Mitra }\end{array}$ & 7,17 & 6,83 & 6,33 & 310,16 \\
\hline 23 & $\begin{array}{l}\text { Struktur organisasi Mitra yang } \\
\text { berubah-ubah }\end{array}$ & 5,50 & 4,17 & 3,67 & 84,03 \\
\hline 24 & $\begin{array}{l}\text { Keterbatasan personil Telkom } \\
\text { untuk pelaksanaan test }\end{array}$ & 5,83 & 4,17 & 3,50 & 85,07 \\
\hline \multicolumn{6}{|c|}{ Kegagalan Instalasi } \\
\hline 25 & $\begin{array}{l}\text { Perbaikan pekerjaan yang sudah } \\
\text { selesai (rework) }\end{array}$ & 7,17 & 6,67 & 5,67 & 270,74 \\
\hline 26 & $\begin{array}{lr}\text { Kurangnya } & \text { efektifitas } \\
\text { perencanaan dan } & \text { penjadwalan } \\
\text { pekerjaan } & \end{array}$ & 6,83 & 5,50 & 4,17 & 156,60 \\
\hline 27 & $\begin{array}{l}\text { Penambahan pekerjaan oleh } \\
\text { owner }\end{array}$ & 6,67 & 5,67 & 4,50 & 170,00 \\
\hline 28 & $\begin{array}{l}\text { Perubahan desain di tengah } \\
\text { pekerjaan }\end{array}$ & 6,50 & 5,17 & 4,50 & 151,13 \\
\hline 29 & $\begin{array}{l}\text { Kesalahan mengeterprestasikan } \\
\text { gambar/ spesifikasi }\end{array}$ & 6,83 & 5,50 & 3,33 & 125,28 \\
\hline 30 & $\begin{array}{l}\text { Keterlambatan } \\
\text { perijinan/sitac/ } \\
\text { RLN/ pengurusan } \\
\text { ketiga }\end{array}$ & 7,67 & 6,33 & 6,17 & 299,43 \\
\hline 31 & $\begin{array}{l}\text { Kurangnya komunikasi dan } \\
\text { koordinasi }\end{array}$ & 7,17 & 6,50 & 5,67 & 263,97 \\
\hline 32 & $\begin{array}{l}\text { Bertepatan dengan hari libur/ } \\
\text { perayaan besar }\end{array}$ & 4,17 & 3,33 & 2,67 & 37,04 \\
\hline \multicolumn{6}{|c|}{ Kegagalan Integrasi } \\
\hline 33 & Ketersedian alokasi logic & 6,00 & 4,17 & 3,33 & 83,33 \\
\hline 34 & $\begin{array}{l}\text { Kesalahan } \\
\text { perangkat }\end{array}$ & 6,17 & 4,33 & 3,33 & 89,07 \\
\hline
\end{tabular}




\begin{tabular}{|c|c|c|c|c|c|}
\hline \multirow{2}{*}{ No. } & Potential Failure Mode & \multicolumn{3}{|c|}{ Average } & \multirow{2}{*}{$R P N$} \\
\hline & (Risk Event) & $S$ & $O$ & $D$ & \\
\hline 35 & $\begin{array}{l}\text { Kesalahan konfigurasi network } \\
\text { telkom }\end{array}$ & 6,50 & 5,33 & 3,00 & 104,00 \\
\hline 36 & $\begin{array}{l}\text { Keterlambatan } \\
\text { ruangan Telkom }\end{array}$ ijin masuk & 4,83 & 3,33 & 3,33 & 53,70 \\
\hline \multicolumn{6}{|c|}{ Kegagalan Administrasi } \\
\hline 37 & $\begin{array}{l}\text { Dokumentasi proyek yang tidak } \\
\text { memadai }\end{array}$ & 5,83 & 4,00 & 5,17 & 120,56 \\
\hline 38 & $\begin{array}{ll}\text { Banyak aplikasi } & \text { yang } \\
\text { digunakan dalam proyek } & \end{array}$ & 5,17 & 4,67 & 5,00 & 120,56 \\
\hline 39 & $\begin{array}{l}\text { Update sistem yang tidak sesuai } \\
\text { prosedur }\end{array}$ & 6,50 & 5,00 & 3,83 & 124,58 \\
\hline 40 & $\begin{array}{l}\text { Kesalahan dokumen dengan } \\
\text { kondisi lapangan }\end{array}$ & 6,67 & 5,00 & 3,83 & 127,78 \\
\hline 41 & $\begin{array}{l}\text { Koordinasi dengan witel dan } \\
\text { E\&D }\end{array}$ & 5,50 & 4,33 & 4,50 & 107,25 \\
\hline 42 & $\begin{array}{l}\text { Kesalahan perhitungan nilai } \\
\text { realisasi proyek }\end{array}$ & 6,67 & 6,50 & 6,50 & 281,67 \\
\hline \multicolumn{5}{|c|}{ TOTAL } & $6.403,77$ \\
\hline
\end{tabular}

Setelah diperoleh nilai RPN untuk seluruh risiko, ditentukanlah prioritas dengan menggunakan diagram pareto. Sebelum membuat diagram pareto risiko diurutkan berdasarkan nilai RPN tertinggi, lalu dilanjut dengan membuat diagram pareto gambar 3.

Gambar 3

Diagram Pareto RPN

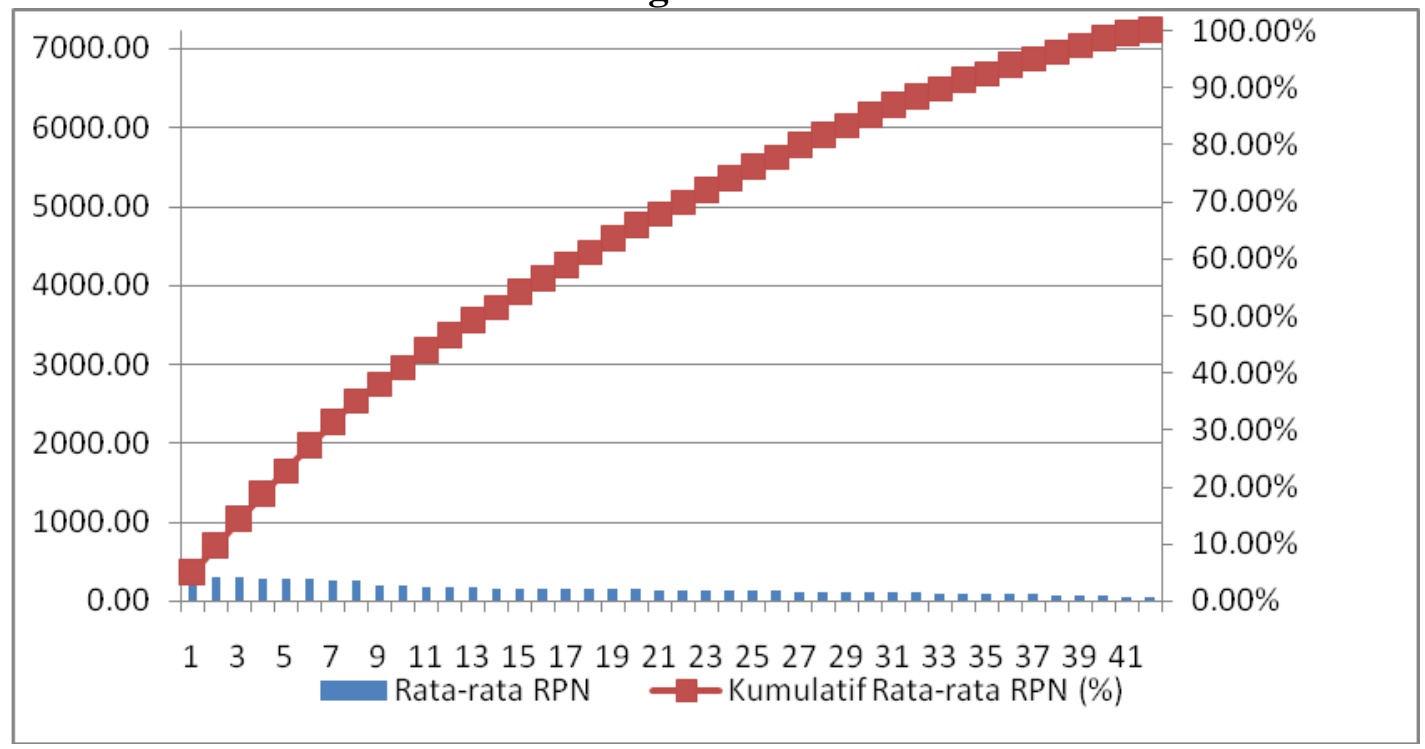

Dari diagram diperoleh risiko yang dijadikan prioritas untuk dimitigasi, terdapat 8 risiko. 
Tabel 7

Prioritas Risiko

\begin{tabular}{|l|c|c|}
\hline \multicolumn{2}{|c|}{ Risk Event } & $\begin{array}{c}\text { Rata-rata } \\
R P N\end{array}$ \\
\hline $\begin{array}{l}\text { Keterbatasan kualifikasi tenaga kerja } \\
\text { Mitra }\end{array}$ & 1 & 310,16 \\
\hline $\begin{array}{l}\text { Adanya new item dalam pekerjaan yang } \\
\text { belum terdapat dalam List of Materials }\end{array}$ & 2 & 302,17 \\
\hline $\begin{array}{l}\text { Keterlambatan pengurusan } \\
\text { perijinan/sitac/ PLN/ pihak ketiga }\end{array}$ & 3 & 299,43 \\
\hline $\begin{array}{l}\text { Kesalahan perhitungan nilai realisasi } \\
\text { proyek }\end{array}$ & 4 & 281,67 \\
\hline Keterbatasan jumlah tenaga kerja Mitra & 5 & 271,74 \\
\hline $\begin{array}{l}\text { Perbaikan pekerjaan yang sudah selesai } \\
\text { (rework) }\end{array}$ & 6 & 270,74 \\
\hline Kurangnya komunikasi dan koordinasi & 7 & 263,97 \\
\hline $\begin{array}{l}\text { Keterlambatan pemesanan material ke } \\
\text { pabrik }\end{array}$ & 8 & 250,56 \\
\hline
\end{tabular}

\section{KESIMPULAN}

Berdasarkan hasil pengolahan dan analisis data dapat disimpulkan beberapa hal, antara lain:

1. Setelah dilakukan wawancara dengan Manager Integrasi dan seluruh staffnya yang terlibat langsung pada proyek modernisasi perangkat RK diperoleh 9 kegagalan yang dikelompokan berdasarkan aktivitas proyek. Yang termasuk 9 kegagalan tersebut yaitu pertama proses preparing terdiri dari kegagalan kontrak, kegagalan desain, dan kegagalan survey. Lalu proses delivery yang terdiri dari kegagalan material dan kegagalan delivery. Proses ketiga yaitu proses instalasi dan integrasi yaitu kegagalan SDM, kegagalan instalasi, dan kegagalan integrasi. Dan yang terakhir proses closing yaitu kegagalan administrasi. Selanjutnya dari 9 kegagalan tersebut teridentifikasi 42 risiko yang menyebabkan keterlambatan proyek yang akan dibuatkan prioritas mitigasinya.

2. Untuk menentukan prioritas dan langkah mitigasinya diterapkan langkah-langkah yang terdapat pada PMBOK. Analisis dilakukan dengan bantuan metode FMEA dan juga diagram pareto. Langkah yang dilakukan yaitu menetapkan nilai severity, occurrence, detection untuk memperoleh nilai RPNnya. Nilai inilah yang akan dijadikan untuk penentuan risiko yang akan dijadikan prioritas untuk dimitigasi. Diperoleh 8 risiko yang berdampak besar menyebabkan keterlambatan proyek modernisasi perangkat RK. 
3. Dari 8 risiko yang ditetapkan sebagai prioritas, dapat mencegah dan mengantisipasi keterlambatan proyek. Maka peneliti mengusulkan upaya mitigasi sebagai berikut:

a. Risiko keterbatasan kualifikasi tenaga kerja Mitra dengan nilai RPN tertinggi yaitu 310,16. Salah satu cara memitigasinya yaitu memilih mitra dengan mencocokkan kualifikasi dengan kontrak.

b. Risiko adanya new item dalam pekerjaan yang belum terdapat dalam List of Materials, nilai RPN 302,17. Salah satu cara memitigasinya yaitu melalukan inisiasi diawal.

c. Risiko keterlambatan pengurusan hal yang berkaitan dengan instalasi perangkat misalnya perijinan/sitac/PLN/ pihak ketiga. Risiko ini memiliki nilai RPN yaitu sebesar 299,43. Salah satu cara memitigasinya yaitu dengan mempersiapkan langsung setelah DRM (node sudah pasti) untuk pengurusannya yang dilakukan secara paralel antara sitac dan PLN.

d. Risiko dengan nilai RPN 281,67 yaitu kesalahan perhitungan nilai realisasi proyek. Langkah mitigasinya antara lain memastikan nilai yang ada didokumen sudah sama dengan jumlah yang ada di lokasi.

e. Risiko keterbatasan jumlah tenaga kerja Mitra dengan nilai RPN yaitu 271,74. Salah satu cara mitigasinya yaitu dengan cara memastikan mitra untuk membuat struktur organisasi dan melampirkan jumlah tenaga kerja yang dimiliki.

f. Risiko perbaikan pekerjaan yang sudah selesai (rework) dengan nilai RPN sebesar 270,74. Untuk mitigasinya bisa dengan cara melakukan kontrol kelapangan oleh pihak telkom dan mitra selama proses pengerjaan sehingga jika ada yang tidak sesuai dapat langsung diperbaiki.

g. Risiko kurangnya komunikasi dan koordinasi dengan nilai RPN sebesar 263,97. Salah satu cara mitigasinya yaitu dengan cara membuat laporan mingguan secara rutin yang dikirimkan ke E\&D.

h. Risiko keterlambatan pemesanan material ke pabrik dengan nilai RPN sebesar 250,56. Salah satu cara mitigasinya yaitu dengan cara menyepakati jumlah node tidak dapat ditambah atau dikurangi tepat setelah DRM.

\section{REFERENSI}

Bahrami, Mahdi (2012), Innovation and Improvements In Project Implementation and Management; Using FMEA Technique, Journal Social and Behavioral Sciences 41 ( 2012 ) $418-425$.

Carlson, Carl S (2012), Effective FMEAs: Achieving Safe, Reliable, and Economical Products and Processes Using Failure Mode and Effects Analysis, John Wiley \& Sons, Inc., New Jersey.

Amalia, Ridhati (2012), Analisa Penyebab Keterlambatan Proyek Pembangunan Sidoarjo Town Square Menggunakan Metode Fault Tree Analysis (FTA), Institut Teknologi Sepuluh Nopember.

Firdaus, Rachmat dan Tedjo Sukmono, Perbaikan Proses Produksi Muffler Dengan Metode FMEA Pada industri kecil di Sidoarjo, Jurnal, Universitas Muhammadiyah Sidoarjo.

Project Management Institute, Inc. (2008), A Guide to the Project Management Body of Knowledge: PMBOK Guide, Fourth Edition, Pennsylvania.

Utama, Yuris Permana Yoga (2008). Manajemen Resiko di PT. Industri Kereta Api (Persero) Untuk Menghadapi Ketidakpastian Supply Chain, Tesis, MMT ITS, Surabaya. 